\title{
Hidrolisis Secara Enzimatis Protein Bungkil Biji Nyamplung (Calophyllum inophyllum) Menggunakan Bromelain
}

\author{
Enzymatic Hydrolysis of Protein from Nyamplung (Calophyllum inophyllum) Oilseed Press \\ Cake Using Bromelain
}

\section{Ratih Restiani}

Prodi Biologi Fakultas Bioteknologi, Universitas Kristen Duta Wacana Yogyakarta

Jl. Dr. Wahidin Sudirohusodo No. 5 - 25, Yogyakarta

Email: ratih.restiani@staff.ukdw.ac.id

\begin{abstract}
Nyamplung has seeds with high oil content that makes it potentially used as a material for biofuel production. The process of extracting oil from nyamplung seeds produce waste in the form of oilseed-press cake with high protein content that has not been used optimally. One of the alternative process to utilize the protein in oilseed press-cake into valuable products is through enzymatic hydrolysis of nyamplung protein using bromelain. Bromelain is a group of cysteine endoprotease with broad specificity to cut the amino acid residues including arginine, lysine, tyrosine, and phenylalanine, thus its application for nyamplung oilseeds protein hydrolysis can produce a high degree of hydrolysis (DH). This study aimed to determine the content of protein from nyamplung oilseed press cake protein and to determine the effect of bromelain concentration also time of hydrolysis on the DH of the protein hydrolysate. The methods of this research consists of two steps:1) proximate analysis of nyamplung oilseed presscake, 2) analysis of DH from protein hydrolysis using bromelain with the variation of enzyme concentration $(2,6$ and 10) $\%(w / v)$, time of hydrolysis $(0,30,60,120,180$ and 240$)$ minutes at pH 7 and temperature at $45^{\circ} \mathrm{C}$. The results showed that the increase of enzyme concentration at $10 \%(w / v)$ with enzyme activity $(27,04 \mathrm{U} / \mathrm{gr}$ substrate) resulted the highest $\mathrm{DH}(6,43 \%)$ with time of hydrolysis at 240 minutes.
\end{abstract}

Keywords: Bromelain , Degree of Hydrolysis , Nyamplung

\begin{abstract}
Abstrak
Nyamplung mengandung minyak yang cukup tinggi sehingga membuatnya potensial untuk digunakan sebagai bahan dasar pembuatan biofuel. Proses ekstraksi minyak dari biji nyamplung menghasilkan limbah padat dalam bentuk bungkil biji nyamplung yang masih memiliki kandungan protein dan belum optimal pemanfaatannya. Salah satu alternatif untuk mengolah protein dalam bungkil menjadi produk yang lebih bernilai adalah melalui hidrolisis secara enzimatis menggunakan bromelain. Bromelain adalah kelompok sistein endoprotease yang memiliki spesifisitas pemotongan yang cukup luas terhadap berbagai residu asam amino meliputi arginin, lisin, tirosin, dan fenilalanin sehingga aplikasi bromelain dalam hidrolisis protein bungkil biji nyamplung diharapkan dapat menghasilkan derajat hidrolisis (DH) yang tinggi. Penelitian ini bertujuan untuk menentukan kandungan protein dalam bungkil biji nyamplung, dan menentukan pengaruh konsentrasi enzim serta waktu hidrolisis terhadap DH hidrolisat protein. Metode penelitian terdiri dari 2 tahapan yaitu : 1) analisis proksimat bungkil biji nyamplung dan 2) analisis DH hidrolisat protein menggunakan bromelain dengan variasi konsentrasi enzim $(2,6$ dan 10)\% (b/v), waktu hidrolisis $(0,30,60,120,180$ dan 240) menit pada pH 7 dan temperatur $45^{\circ} \mathrm{C}$. Hasil menunjukkan bahwa peningkatan konsentrasi enzim sebesar $10 \%$ dengan aktivitas enzim yang terukur (27,04 U/gr substrat) menghasilkan DH tertinggi $(6,43 \%)$ dengan waktu hidrolisis 240 menit.
\end{abstract}

Kata kunci: Bromelain, Derajat Hidrolisis (DH), Nyamplung 


\section{Pendahuluan}

Nyamplung (Calophyllum inophyllum) merupakan salah satu tanaman berbiji yang memiliki kandungan minyak cukup tinggi yaitu sebesar $40-73 \%$ seperti beberapa jenis tanaman berbiji yang mengandung minyak lainnya atau non-edible fruit seperti jarak pagar $40-60 \%$ dan sawit 46-54\% (Masyhud, 2008). Tingginya kandungan minyak dalam biji nyamplung menjadikannya potensial untuk dimanfaatkan sebagai bahan dasar pembuatan biofuel. Limbah utama yang dihasilkan dari proses tersebut adalah bungkil biji nyamplung yang pemanfaatannya masih terbatas sebagai pakan ternak dan fertilizer (Devapalin dkk.,1982; Prima, 2010). Terbatasnya pemanfaatan protein bungkil biji nyamplung membuka peluang untuk dapat mengolah limbah bungkil menjadi produk yang bernilai.

Salah satu alternatif yang dapat dilakukan untuk memanfaatkan protein dalam bungkil adalah melalui hidrolisis protein secara enzimatis. Hidrolisis protein secara enzimatis memiliki kelebihan dibandingkan hidrolisis protein dengan asam dan alkali karena produk peptida yang dihasilkan memiliki komposisi dan urutan asam amino yang spesifik sesuai dengan jenis protease yang digunakan. Selain itu, hidrolisis protein secara enzimatis berlangsung pada kondisi yang lebih mild (tidak pada kondisi ekstrim) dibandingkan menggunakan asam atau basa sehingga tidak merusak asam amino yang dihasilkan. Hidrolisis menggunakan $\mathrm{NaOH}$ cenderung merusak asam amino esensial (triptofan, sistein atau serin) dan mengubah konformasi struktur L-asam amino menjadi Dasam amino, bentuk ini tidak dapat dikonsumsi oleh manusia (Whitaker, 2003; Pardo $d k k$., 2000).

Hidrolisat protein yang dihasilkan melalui hidrolisis protein secara enzimatis telah dimanfaatkan secara luas diantaranya untuk suplemen bernutrisi, pangan fungsional, meningkatkan cita rasa dalam makanan, pemutih kopi, bahan kosmetik dan fortifikasi ekstrak buah dan minuman ringan (Zheng $d k k$., 2006). Berbagai penelitian hidrolisis protein secara enzimatis yang telah banyak dikembangkan diantaranya memanfaatkan berbagai sumber protein nabati maupun hewani seperti protein susu, jagung, kuning telur, chickpea, bungkil wijen, biji-biji yang menghasilkan minyak (oilseedprotein), makarel dan limbah ikan yellowfish (Liu dan Chiang, 2008).

Bromelain merupakan kelompok endoprotease yang umum digunakan dalam hidrolisis protein. Selain itu, bromelain memiliki spesifisitas pemotongan yang cukup luas terhadap residu asam amino penyusun substratnya meliputi arginin, lisin, tirosin, dan fenilalanin sehingga mampu menghasilkan derajat hidrolisis yang tinggi (Whitaker, 2003). Bromelain telah banyak diaplikasikan pada berbagai proses dalam industri makanan seperti pembuatan hidrolisat protein, stabilitator dalam industri bir, pengempuk dalam industri pengolahan daging dan ikan, industri pembuatan kue, industri penyamakan kulit dan tekstil (Haslaniza dkk., 2010)

Kondisi selama proses hidrolisis dapat dikontrol melalui derajat hidrolisis (DH) yang dihasilkan. Derajat hidrolisis merupakan persentase (\%) gugus amino bebas yang dilepaskan selama proses hidrolisis terhadap total nitrogen yang terdapat dalam substrat. Dari setiap ikatan peptida yang dihidrolisis dari protein akan dilepaskan gugus amino bebas, sehingga pengukuran derajat hidrolisis dengan metode Trinitrobenzene sulfonic acid (TNBS) dihitung berdasarkan gugus amino bebas yang terbentuk (Adler-Nissen, 1979).

Derajat hidrolisis (DH) protein sangat ditentukan oleh beberapa faktor diantaranya jenis protease yang digunakan, konsentrasi enzim, temperatur, $\mathrm{pH}$ dan waktu hidrolisis (Bjoern $d k k$., 2000 ; Haslaniza $d k k ., 2010$ ). Oleh karena itu, sangat penting untuk mengoptimasi beberapa faktor tersebut sehingga didapatkan DH yang optimal.

Penelitian ini bertujuan untuk menentukan kandungan protein dalam bungkil biji nyamplung dan menentukan pengaruh konsentrasi enzim bromelain serta waktu hidrolisis terhadap Derajat Hidrolisis (DH) hidrolisat protein bungkil biji nyamplung.

\section{Metode Penelitian}

Bahan utama yang digunakan dalam penelitian ini adalah bungkil biji nyamplung 
yang diperoleh dari Pabrik Biodiesel di Ketawangrejo, Purworejo, Jawa Tengah. Bungkil yang telah diperoleh selanjutnya disimpan dalam ruang pendingin pada suhu $20^{\circ} \mathrm{C}$ sampai digunakan. Bahan utama kedua yang digunakan dalam penelitian ini adalah bromelain komersial Merck Germany. Bahan kimia yang digunakan dalam penelitian ini adalah kasein Bovine Milk Sigma, Bovine Serum Albumin (BSA) L-tirosin, L-leusin, Trinitrobenzene Sulfonic Acid (TNBS), $\mathrm{NaOH}$, $\mathrm{HCl}, \mathrm{Na}_{2} \mathrm{CO}_{3}, \mathrm{CuSO}_{4} .5 \mathrm{H}_{2} \mathrm{O}, \mathrm{K}$-Tartrat, reagen Folin Ciocalteau, phospat mono basis dan dibasis, asetat mono basis dan dibasis, Trichloroacetic Acid (TCA).

Alat yang digunakan pada penelitian ini adalah ayakan 50 mesh, waterbath shaker (Julabo SW23), pH meter (Schott), vortex, mikro pipet, oven, spektrofotometer (Shimadzu UV-visible spectrophotometer UV-1650 PC), spektrofotometer visible (Genesys), sentrifuge (Damon/IEC Divisoin) yang dioperasikan pada kecepatan $3000 \mathrm{~g}$ dan alat gelas untuk analisis.

\section{Preparasi Tepung Bungkil Biji Nyamplung}

Preparasi tepung bungkil biji nyamplung dilakukan dengan proses pengecilan ukuran bungkil biji hasil pengepresan dan pengeringan yang dihasilkan dari pabrik biodiesel di Ketawangrejo menggunakan desintegrator. Bubuk kasar yang dihasilkan diayak menggunakan ayakan 50 mesh. Bubuk yang lolos proses pengayakan disimpan dalam plastik klip dan disimpan dalam lemari pendingin pada suhu $-20^{\circ} \mathrm{C}$.

\section{Hidrolisis Protein Bungkil secara Enzimatis}

Proses hidrolisis dilakukan menurut metode Liu dan Chiang (2008) yang telah dimodifikasi. Tahap pertama dilakukan pengukuran aktivitas enzim bromelain komersial yang akan digunakan dalam proses hidrolisis. Setelah mengukur aktivitas (U/ml) bromelain komersial yang akan digunakan, selanjutnya disiapkan variasi konsentrasi enzim bromelain $(2,6,10) \%(b / v)$ yang sudah dianalisis tadi untuk proses hidrolisis protein bungkil biji nyamplung.

Analisis dilakukan dengan mengukur aktivitas proteolitik enzim terhadap substrat kasein (prosedur Sigma). Kasein dilarutkan dalam $0,05 \mathrm{M}$ buffer phospat $\mathrm{pH} 7$ sebesar $0,65 \%(\mathrm{~b} / \mathrm{v})$. Suspensi dihomogenisasi dengan vortex selama 10 detik dan didistribusikan ke dalam tabung reaksi masing-masing $5 \mathrm{~mL}$ selanjutnya di pre-inkubasi selama 10 menit. Enzim bromelain bubuk dilarutkan dalam 0,05M buffer phospat $\mathrm{pH} 7$ dengan konsentrasi 0,1 $\mathrm{gr} / \mathrm{ml}$. Selanjutnya, sebanyak $1 \mathrm{ml}$ enzim ditambahkan ke dalam tabung yang telah berisi substrat kasein dan campuran divortex kemudian diinkubasi pada suhu $37^{\circ} \mathrm{C}$ selama 10 menit lalu reaksi dihentikan dengan menambahkan $5 \mathrm{ml}$ reagen TCA $110 \mathrm{mM}$ dan dilanjutkan inkubasi selama 30 menit pada suhu $37^{\circ} \mathrm{C}$ kemudian disentrifugasi selama 15 menit pada $3000 \mathrm{~g}$ untuk memisahkan materi yang tidak dapat larut. Analisis dilanjutkan dengan menambahkan reagen $500 \mathrm{mM} \mathrm{Na} \mathrm{CO}_{3}$ sebanyak $5 \mathrm{ml}$ dan $1 \mathrm{ml}$ reagen pewarna Follin (1:4) ke dalam $2 \mathrm{ml}$ supernatan hasil sentrifugasi. Reaksi dilanjutkan dengan memvortex campuran, menginkubasi selama 30 menit dalam waterbath suhu $37^{\circ} \mathrm{C}$ dan dilanjutkan dengan peneraan menggunakan spektrofotometer pada panjang gelombang 660 nm.

Tahap kedua dalam proses ini adalah hidrolisis protein tepung bungkil biji nyamplung menggunakan bromelain yang telah dianalisis aktivitas proteolitiknya. Bubuk bungkil dilarutkan dalam $0,05 \mathrm{M}$ buffer phospat $\mathrm{pH} 7$ dengan total perbandingan bungkil : buffer sebesar 1:10 (b/v). Suspensi tersebut selanjutnya diatur $\mathrm{pH}$ nya sampai $\mathrm{pH} 7$ menggunakan $1 \mathrm{~N}$ $\mathrm{NaOH}$ dan dilanjutkan pre-inkubasi dalam waterbath shaker selama 20 menit pada suhu $45^{\circ} \mathrm{C}$ dengan kecepatan $100 \mathrm{rpm}$. Setelah diinkubasi, dilanjutkan dengan menambahkan enzim yang telah dilarutkan dalam buffer phospat $\mathrm{pH} 7$ berdasarkan variasi konsentrasi enzim $(2 ; 6 ; 10) \%(\mathrm{~b} / \mathrm{v})$ selama 240 menit.

Setelah proses hidrolisis berlangsung selama 240 menit, kemudian dipilih satu konsentrasi yang menunjukkan DH tertinggi untuk digunakan dalam proses hidrolisis variasi waktu. Dari hidrolisis dengan variasi konsentrasi enzim, kemudian dipilih satu konsentrasi untuk masing-masing enzim yang menunjukkan DH paling tinggi untuk digunakan dalam pengamatan variasi waktu terhadap DH. Pengamatan terhadap variasi waktu dilakukan 
pada interval waktu $(0 ; 30 ; 60 ; 120 ; 180 ;$ dan 240) menit.

Proses hidrolisis secara enzimatis dihentikan reaksinya dengan penambahan 110 mM TCA (1:55) sebanyak $5 \mathrm{ml}$. Hidrolisat protein dianalisis derajat hidrolisisnya (DH) dengan metode TNBS dan dianalisis protein terlarutnya.

\section{Analisis proksimat}

Analisis proksimat dilakukan terhadap biji nyamplung segar dan bubuk bungkil biji nyamplung menurut AOAC (1990) yaitu, analisis kadar minyak dengan metode Soxhlet, analisis kadar protein dengan metode Mikro Kjeldahl, analisis kadar air dengan metode thermogravimetry, analisis kadar abu dengan metode pengabuan cara kering, dan analisis kadar karbohidrat dengan metode by different.

\section{Analisis Protein Terlarut}

Protein terlarut dianalisis dengan metode Lowry dkk., (1951). Penentuan kadar protein supernatan dilakukan dengan menambahkan 1 $\mathrm{ml}$ reagen $\mathrm{D}$ (campuran larutan $\mathrm{A}, \mathrm{B}$, dan $\mathrm{C}$ dengan perbandingan 20:1:1 (v/v) ke dalam $1 \mathrm{ml}$ supernatan. Reagen A berisi $2 \% \mathrm{Na}_{2} \mathrm{CO}_{3}$ dalam larutan $\mathrm{NaOH} 0,1 \mathrm{~N}$. Reagen B berisi $1 \% \mathrm{CuSO}_{4}$ dalam aquades dan reagen $\mathrm{C}$ berisi natrium kalium tartrat $\left(\mathrm{NaKC}_{4} \mathrm{H}_{4} \mathrm{O}_{6}\right)$. Larutan sampel dihomogenasi dengan vortex selama 3 detik, dan diinkubasi selama 15 menit. Kemudian larutan sampel ditambah $3 \mathrm{ml}$ reagen E Follin Ciocalteu, dihomogenasi dengan vortex selama 3 detik, lalu diinkubasi selama 45 menit pada ruang gelap. Kemudian sampel ditera absorbansinya pada panjang gelombang $750 \mathrm{~nm}$.

\section{Protein terlarut (mg protein $/ \mathrm{mL})$ :}

$\frac{(\text { absorbansi sampel-blangko }) \times \mathrm{fp}}{A}$

Keterangan :

fp : faktor pengenceran

A : nilai A dari persamaan kurva standar Lowry

\section{Analisis Gugus Amino Bebas}

Analisis gugus amino bebas digunakan dalam penentuan besarnya derajat hidrolisis (DH) dengan menggunakan metode TNBS
Adler-Nissen (1979) yang telah dimodifikasi. Sebanyak 0,25 $\mathrm{mL}$ sampel ditambah dengan 2 $\mathrm{mL}$ buffer phospat $\mathrm{pH} 8,2$. Kemudian sampel ditambah 2 mL larutan Trinitrobenzene Sulfonic Acid (TNBS) 0,01\% (v/v) dan dihomogenisasi dengan vortex selama 3 detik. Campuran tersebut diinkubasi selama 1 jam pada suhu $50^{\circ} \mathrm{C}$ dalam waterbath tertutup. Reaksi dihentikan dengan menambahkan $4 \mathrm{~mL}$ larutan $\mathrm{HCl} 0,1 \mathrm{~N}$. Kemudian sampel didinginkan dan diinkubasi selama 30 menit pada suhu ruang dalam ruang gelap. Peneraan absorbansi dilakukan pada panjang gelombang $340 \mathrm{~nm}$.

Jumlah amino bebas ( $\mu \mathrm{mol}$ leusin/mL) :

(absorbansi sampel-blangko) $x \mathrm{fp}$

Keterangan :

Fp : faktor pengenceran

A : nilai A pada persamaan kurva standar TNBS

Perhitungan derajat hidrolisis (DH) dengan metode TNBS oleh Adler-Nissen, (1979) dalam Spellman (2003):

$$
\frac{D H=A N 2-A N 1 \times 100 \%}{N p b}
$$

\section{Keterangan :}

$\mathrm{AN}_{1}$ :kandungan gugus amino bebas substrat sebelum dihidrolisis ( $\mu \mathrm{mol}$ leusin/mL)

$\mathrm{AN}_{2}$ :kandungan gugus amino bebas substrat setelah dihidrolisis ( $\mu \mathrm{mol}$ leusin $/ \mathrm{mL}$ )

Npb :kandungan total ikatan peptida pada substrat ( $\mu \mathrm{mol}$ leusin/ml)

\section{Hasil dan Pembahasan}

\section{Analisis Proksimat Bungkil Biji Nyamplung}

Bubuk bungkil biji nyamplung dari biji nyamplung segar yang telah melalui proses pengeringan, pengepresan dan pengecilan ukuran dianalisis komposisi proksimatnya. Hasil analisis proksimat dapat dilihat pada Tabel 1.

Dari (Tabel 1.), dapat diketahui bahwa lemak merupakan komponen terbesar $44,76 \%$ dalam biji nyamplung segar, sehingga membuatnya menjadi bahan dasar dalam pembuatan biodiesel. Setelah proses pengeringan dan pengepresan biji segar, kandungan minyak 
(lemak) dalam bungkil biji nyamplung menurun sebesar 33,49\% diikuti dengan penurunan kadar air sebesar $31,25 \%$, penurunan kadar air ini sangat mungkin disebabkan karena proses pengeringan biji nyamplung segar sebelum pengepresan minyak.

Dari hasil pengepresan (ekstraksi minyak) menghasilkan peningkatan kandungan protein dalam bungkil biji nyamplung menjadi sebesar $21,56 \%$ dibandingkan protein dalam biji nyamplung segar $(3,20 \%)$. Hal ini disebabkan karena sebagian besar minyak yang terdapat dalam biji nyamplung sudah diekstrak keluar sehingga minyak yang tersisa di dalam bungkil biji nyamplung hanya sebesar $14,99 \%$ dan disertai dengan meningkatnya beberapa komponen penyusun bungkil lain meliputi kandungan karbohidrat sebesar 45,23\% dan abu sebesar 7,30\%.

Kandungan protein dalam bubuk bungkil biji nyamplung cukup tinggi jika dibandingkan tepung jagung defatted (20\%) (Barbieri dan Casiraghi, 2007) dan protein kernel kelapa sawit defatted (17,6\%) (Zarei $d k k ., 2012)$. Melalui kandungan protein dalam bungkil biji nyamplung yang relatif cukup tinggi tersebut maka menjadikannya potensial untuk dimanfaatkan menjadi produk yang bernilai bahkan sebelum didefatting menggunakan heksan dan selanjutnya dapat langsung dimanfaatkan dalam proses hidrolisis secara enzimatis.

\section{Pengaruh Konsentrasi Enzim terhadap Derajat Hidrolisis}

Konsentrasi enzim sangat menentukan besarnya derajat hidrolisis protein. Faktor ini merupakan salah satu faktor penting yang harus dipertimbangkan dalam menghasilkan hidrolisat protein dengan $\mathrm{DH}$ yang tinggi.

Pada penelitian ini digunakan beberapa variasi konsentrasi enzim yaitu $(2,6,10) \%(\mathrm{~b} / \mathrm{v})$ dengan masing-masing aktivitas enzim sebesar $(5,40 ; 16,22 ;$ dan 27,04$)$ U/gr substrat (Gambar $1)$.

Tabel 1. Komposisi proksimat biji segar dan bubuk bungkil biji nyamplung

\begin{tabular}{lcc}
\hline \hline Kandungan $(\% \mathbf{d b})$ & Biji Segar & Bubuk Bungkil \\
\hline \hline Kadar protein & 3,20 & 21,56 \\
Kadar lemak & 44,76 & 14,99 \\
Kadar abu & 1,38 & 7,30 \\
Kadar air & 35,04 & 10,95 \\
Kadar karbohidrat & 15,62 & 45,23 \\
\hline \hline
\end{tabular}

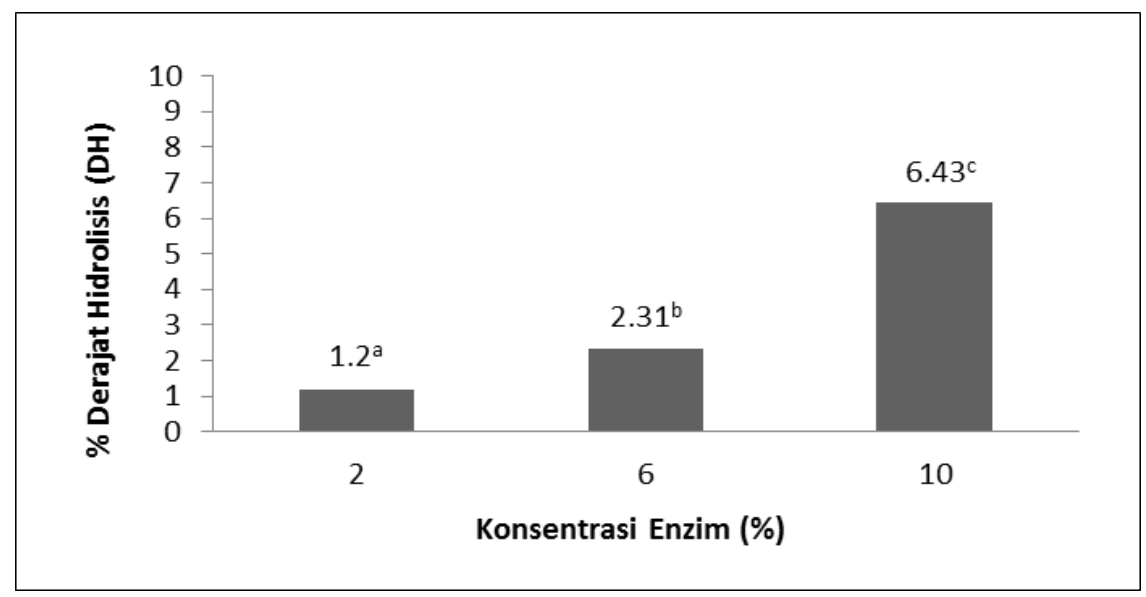

Gambar 1. Pengaruh variasi konsentrasi bromelain komersial terhadap DH protein bungkil biji nyamplung

Gambar 1, menunjukkan bahwa derajat hidrolisis (DH) meningkat secara signifikan $(\mathrm{p}<0.05)$ seiring dengan peningkatan konsentrasi enzim. Peningkatan konsentrasi enzim menghasilkan hubungan yang linear terhadap peningkatan DH (Kamau dan Lu, 2011). Hal ini 
dapat disebabkan karena ketersediaan enzim dalam jumlah yang besar sehingga dapat meningkatkan kecepatan hidrolisis terhadap substrat yang berada dalam jumlah tetap. Makin banyak jumlah enzim yang ditambahkan maka makin banyak ikatan peptida yang dapat terhidrolisis. Pada level konsentrasi enzim yang lebih rendah, DH yang dihasilkan cenderung lebih rendah karena ketersediaan substrat yang lebih besar dibandingkan jumlah enzim yang tersedia sehingga kecepatan dalam memotong ikatan peptida dalam substrat lebih rendah.

Rendahnya DH pada level konsentrasi enzim yang rendah dapat juga disebabkan karena ketersediaan peptida yang terlarut dalam substrat lebih besar dibandingkan jumlah enzim yang tersedia sehingga hal ini akan menghambat sisi katalitik enzim secara irreversibel. Hasil yang sama juga dilaporkan oleh Kamau dan Lu (2011), yang melaporkan peningkatan DH pada hidrolisis protein whey pada penambahan variasi konsentrasi enzim dari $1 \%-4 \%(\mathrm{~b} / \mathrm{v})$.

DH yang dihasilkan pada konsentrasi bromelain $10 \% \quad(27.04 \mathrm{U} / \mathrm{gr}$ substrat) cukup rendah jika dibandingkan dengan DH yang dihasilkan pada penelitian Zarei $d k k$., (2012), yang menggunakan bromelain dengan konsentrasi enzim lebih rendah yaitu sebesar $2 \%$ terhadap bungkil defatted palm kernel yang mampu menghasilkan DH sebesar 20\% setelah hidrolisis selama 5 jam. Selain itu, DH yang lebih tinggi juga dihasilkan pada hidrolisis defatted protein biji wijen menggunakan bromelain dengan rasio enzim : substrat (E:S) sebesar 2\% selama 240 menit hidrolisis menghasilkan DH sebesar $16,78 \%$. Akan tetapi DH yang dihasilkan dalam penelitian ini masih cenderung lebih besar dibandingkan DH yang dihasilkan pada penelitian Ren $d k k$., (2010), yang menggunakan bromelain pada konsentrasi E/S lebih besar yaitu $20 \%$ (3,0 x 10 4 U/gr) untuk menghidrolisis protein miofibril grass carp hanya mampu menghasilkan DH sebesar 22\%.

Walaupun menggunakan jenis enzim yang sama, tetapi masing-masing proses hidrolisis tersebut menghasilkan besarnya DH yang berbeda. Hal ini dapat disebabkan karena perbedaan jenis protein dalam substrat, jumlah kandungan protein dalam substrat, aktivitas masing-masing bromelain yang digunakan selama proses hidrolisis dan adanya inhibitor yang menghalangi kontak antara substrat dengan enzim sehingga dihasilkan derajat pemotongan ikatan peptida yang berbeda. Hal ini dibuktikan melalui hasil penelitian Liu dan Chiang (2008), yang menggunakan subtrat protein bungkil biji wijen yang sudah didefatted dihidrolisis menggunakan enzim yang sama yaitu bromelain komersial dengan rasio enzim/substrat 1:200 (v/v) selama 240 menit menghasilkan DH yang berbeda dari penelitian ini yaitu mencapai $18 \%$.

Dalam penelitian ini, rendahnya derajat hidrolisis $(\mathrm{DH})$ pada konsentrasi enzim tertinggi $10 \%$ (b/v) sangat mungkin disebabkan karena adanya inhibitor berupa minyak (fase lipid) yang masih terdapat dalam bungkil sehingga menghalangi kontak protein dan enzim (fase aqueous) sehingga menghalangi kontak dengan enzim yang menyebabkan afinitas substrat terhadap sisi katalitik enzim menjadi rendah .

\section{Pengaruh Waktu Hidrolisis terhadap Derajat Hidrolisis}

Selain konsentrasi enzim, proses hidrolisis protein secara enzimatis juga dipengaruhi oleh lama waktu hidrolisis. Pada penelitian ini, untuk menentukan pengaruh antara waktu hidrolisis terhadap besarnya nilai DH maka proses hidrolisis berlangsung selama variasi waktu ( 0 ; $30 ; 60 ; 120 ; 180$; dan 240) menit menggunakan level konsentrasi enzim yang memberikan $\mathrm{DH}$ tertinggi yaitu sebesar $10 \% \quad(\mathrm{~b} / \mathrm{v})$ dengan aktivitas enzim sebesar ( 27,04 U/gr) (Gambar 2)

Gambar 2, menunjukkan bahwa kecepatan hidrolisis meningkat sangat cepat pada awal hidrolisis (30 menit pertama). Setelah 30 menit, kecepatan hidrolisis menunjukkan peningkatan yang tidak signifikan ( $\mathrm{p}>0.05)$.

Peningkatan kecepatan hidrolisis di awal reaksi ini sangat mungkin disebabkan karena pemotongan ikatan peptida mencapai kecepatan maksimal dan selanjutnya aktivitas pemotongan ikatan peptida oleh enzim bromelain mulai menurun karena substrat yang tersedia semakin berkurang dan peptida terlarut atau asam amino bebas yang dihasilkan dari proses hidrolisis itu sendiri menyebabkan penghambatan sisi aktif enzim sehingga enzim tidak mampu untuk melakukan aktivitas pemotongan ikatan peptida dan secara tidak langsung menyebabkan laju hidrolsis mencapai fase stasioner. Pola kurva yang sama juga dilaporkan oleh Zhao $d k k$, 
(2012), yang menghidrolsis rice dreg protein menggunakan 5 jenis protease dengan waktu hidrolisis selama 240 menit dan Kong $d k k$., (2007) yang menghidrolisis gluten pada gandum.

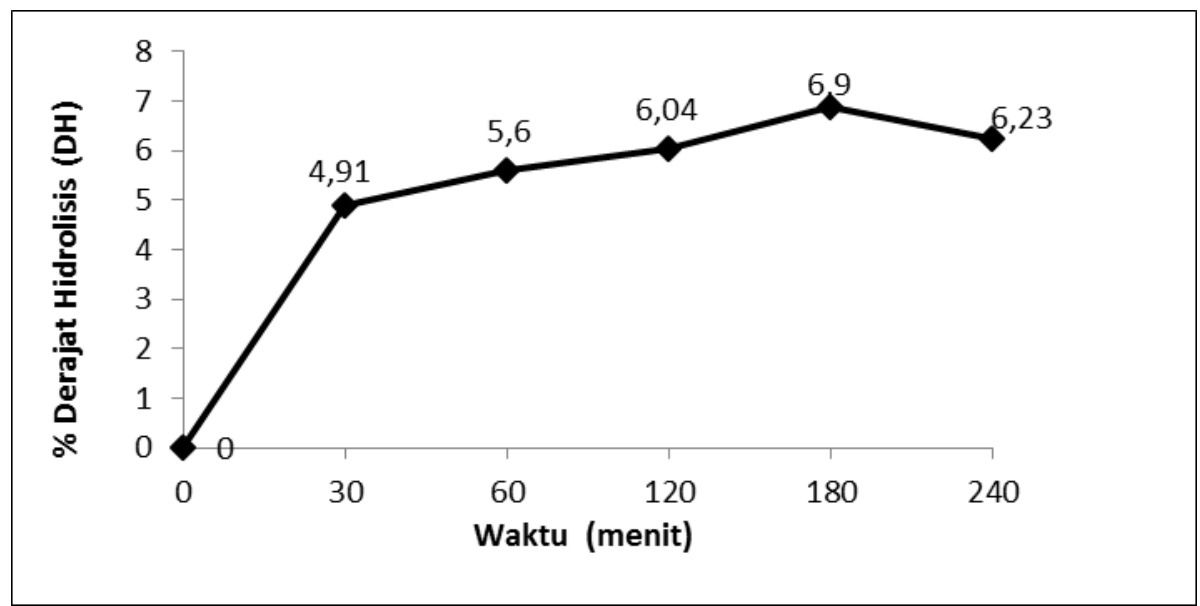

Gambar 2. Pengaruh waktu hidrolisis bromelain terhadap DH protein bungkil biji nyamplung.

\section{Simpulan dan Saran}

\section{Simpulan}

Melalui penelitian ini diperoleh informasi bahwa di dalam bungkil biji nyamplung hasil produksi biodiesel masih mengandung protein yang cukup tinggi untuk diolah menjadi produk yang bernilai dan dimanfaatkan sebagai sumber hidrolisat protein nabati yaitu sebesar $21,56 \%$. Peningkatan konsentrasi enzim sebesar $10 \%$ (b/v) dengan aktivitas enzim 27,04 U/gr substrat dan lama waktu hidrolisis selama 240 menit dapat meningkatkan DH sebesar $6,43 \%$. Tingginya DH tersebut dapat meningkatkan derajat pemotongan ikatan peptida dalam protein sehingga dapat diperoleh potongan peptida dengan karakteristik fungsional yang baru.

\section{Saran}

Perlu dilakukan penelitian lebih lanjut mengenai hidrolisis enzimatis isolat protein bungkil biji nyamplung untuk melihat peningkatan derajat hidrolisis yang dihasilkan serta menguji pengaruhnya terhadap aktivitas antioksidan dari hidrolisat protein yang dihasilkan.

\section{Daftar Pustaka}

Adler-Nissen, J. 1979. Determination of the Degree of Hydrolysis of Food Protein Hydrolysates by Trinitrobenzenesulfonic Acid. Journal of Agricultural and Food Chemistry, 27 (6): 12561262.

Association of Official Analytical Chemists (AOAC). 1990. Official method of analysis Ed 15. USA: AOAC Inc.

Barbieri, R. dan Casiraghi, E.M. 2007. Production of a Food Grade Flour from Deffated Corn Germ Meal. International Journal of Food Science and Technology, 18: 35-41.

Bjoern, L., Lied, E. dan Espe, M. 2000. Enzymatic hydrolysis of byproducts from the fish-filleting industry ; chemical characterization and nutritional evaluation. Journal of The Science of Food and Agriculture, 80: 581-589.

Devapalin, V., Tachorarux, R. dan Arai, K. 1982. Chemical Composition of Some Oil Seeds in Thailand. JARQ, 16 (3): 224-227.

Haslaniza, H., Maskat, M.Y., Wan Aida, W.M. dan Mamout, S. 2010. The effects of enzyme concentration, temperature and incubation time on nitrogen content and degree of hydrolysis of protein precipitate from cockle (Anadara granosa) meat wash water. International Food Research Journal, 17: 147-152.

Kamau, S.M. dan Lu, R. 2011. The Effect of Enzymes and Hydrolysis Conditions on Degree of Hydrolysis and DPPH Radical Scavenging Activity of 
Whey Protein Hydrolysates. Current Research in Dairy Sciences, 3: 25-35.

Kong, X., Zhou, H. dan Qian, H. 2007.Enzymatic preparation and functional properties of wheat gluten hydrolysates. Food Chemistry, 101: 615620 .

Liu, B.L. dan Chiang, P.S. 2008.Production of Hydrolysate with Antioxidative Activity and Functional Properties by Enzymatic Hydrolysis of Defatted Sesame (Sesamum indicum L.). International Journal of Applied Science and Engineering, 6 (2) : 73-83

Lowry, O.H., Rosenbrough, N.J., Farr, A.L. dan Randall, R.J. 1951. Protein Measurement with the Folin Phenol Reagent. Journal of Biology Chemistry, 193: 265-275.

Masyhud. 2008. Tanaman Nyamplung Berpotensi sebagai Energi Biofuel. http://www.dephut.go.id/Htm (diakses tanggal 14 Juni 2011).

Pardo, M.F., Lopez, L.M., Canals, F., Aviles, F.X., Natalucci, C.L. dan Caffini, N.O. 2000. Purification of balansain I, an endopeptidase from unripe fruits of Bromelia balansae Mez (Bromeliaceae). Journal Agriculture of Food Chemistry, 48: 3795-3800.

Prima, M.M. 2010. Isolasi dan Karakterisasi Protein Biji Nyamplung (Caophyllum inophyllum). Thesis. Fakultas Teknologi Pangan dan Hasil Pertanian. FTP Universitas Gadjah Mada Yogyakarta.

Ren, J., Zhao, M., Shi, J., Wang, J., Jiang, Y., Cui, C., Kakuda, Y. dan Sue, S.J. 2010. Purification and Identification of Antioxidant Peptides from Grass carp Muscle Hydrolysates by Consecutive Chromatography and Electrospray
Ionization-Mass Spectrometry. Food Chemistry, $108: 727-736$.

Sharma, A., Khare, S.K. dan Gupta, M.N. 2002.EnzymeAssisted Aqueous Extraction of Peanut Oil. JAOCS, 79 (3): 215-218.

Spellman, D., McEvoya, E., O’Cuinnb, G. dan Geralda, R.J.F. 2003. Proteinase and exopeptidase hydrolysis of whey protein: Comparison of the TNBS, OPA and $\mathrm{pH}$ stat methods for quantification of degree of hydrolysis. International Dairy Journal, 13: 447-453.

Whitaker, J.R. 2003. Effect of temperature on rates of enzyme-catalyzed reactions. Dalam: O.R. Fennema, M. Karel and G.W. Sanderson (eds.). Principles of Enzymologyfor the Food Science. 2nd ed. Marcel Dekker, Inc. Atlanta, Georgia.

Zarei, M., Ebrahimpour, Afshin., Hamid, A.A., Anwar, F. dan Saari, N. 2012. Production of Defatted Palm Kernel Cake Protein Hydrolyste as a Valuable Source of natural Antioxidants. International Journal of Molecular Science, 13: 8097-8111.

Zhao, Q., Xiong, H., Selomulya, C., Chen, X.D., Zhong, H., Wang, S., Sun, W. dan Zhou, Q. 2012. Enzymatic Hydrolysis of Rice Dreg Protein : Effects of enzyme type on the functional properties and antioxidant activities of recovered proteins. Food Chemistry, 134: 13601367.

Zheng, X.Q., Lim, L.T., Liu, X.L., Wang, X.J., Lin, J. dan Li, D. 2006. Production of Hydrolysate with Antioxidative Activity by Enzymatic Hydrolysis of Extruded Corn Gluten. Applied Microbiology and Biotechnology, 73: 763-770. 